\title{
Targeted gene-replacement mutagenesis of dcrA, encoding an oxygen sensor of the sulfate-reducing bacterium Desulfovibrio vulgaris Hildenborough
}

\author{
Rongdian Fu† and Gerrit Voordouw \\ Author for correspondence: Gerrit Voordouw. Tel: +1 4032206388 . Fax: +1 4032899311. \\ e-mail: voordouw@acs.ucalgary.ca
}

Department of Biological Sciences, The University of Calgary, Calgary, Alberta, Canada $\mathrm{T} 2 \mathrm{~N} 1 \mathrm{~N} 4$

\begin{abstract}
A gene-replacement mutagenesis method has been developed for the anaerobic, sulfate-reducing bacterium Desulfovibrio vulgaris Hildenborough and used to delete dcrA, encoding a potential oxygen or redox sensor with homology to the methyl-accepting chemotaxis proteins. A suicide plasmid, containing a cat-marked dcrA allele and a counter-selectable sacB marker was transferred from Escherichia coli S17-1 to $D$. vulgaris by conjugation. Following plasmid integration the desired dcrA deletion mutant (D. vulgaris F100) was obtained in media containing sucrose and chloramphenicol. Southern blot screening was required to distinguish $D$. vulgaris $F 100$ from strains in which the SacB marker was inactivated by transposition of an endogenous IS element. No anaerotactic deficiency has so far been detected in $D$. vulgaris F100, which was found to be more resistant to inactivation by oxygen than the wild-type. Increased transcription of the rbo-rub operon, located immediately downstream from dcrA, was demonstrated by Northern blotting and may be the cause of this unusual phenotype, in view of the recent discovery that Rbo can complement the deleterious effects of superoxide dismutase deficiency in E. coli.
\end{abstract}

Keywords: gene replacement, oxygen sensor, aerotaxis, superoxide dismutase, Desulfovibrio

\section{INTRODUCTION}

Anaerobic, sulfate-reducing bacteria such as those of the genus Desulfovibrio are gradient organisms that position themselves in niches with optimal chemical parameters in soils and aquatic sediments. In sediments these parameters (e.g. the concentrations of oxygen and sulfide) vary over modest distances $(0$ to $20 \mathrm{~cm})$ in the direction perpendicular to the water-sediment interface (Lillebaek, 1995). Steeper gradients and, as a consequence, narrower distributions of bacteria were demonstrated in a $4 \mathrm{~mm}$ thick, photosynthetic biofilm, in which sulfate-reducing bacteria were present. The zone occupied by the bacteria shifted towards the base when surface oxygen concentrations increased during illumination (Ramsing et al., 1993), indicating bacterial

†Present address: The Molecular Sciences Institute, 9894 Genesee Ave 3rd Floor, La Jolla, CA 92037, USA. motility in response to light-induced changes in the oxygen concentration gradient.

We have shown that D. vulgaris Hildenborough has at least one chemoreceptor (DcrA) that serves as a sensor of the oxygen concentration or redox potential of its surroundings (Fu et al., 1994). Although its function in chemotaxis remains to be demonstrated, DcrA has the structural design of the methyl-accepting chemotaxis proteins (MCPs) found in the Enterobacteriaceae, with an N-terminal, periplasmic, sensing domain and a Cterminal, cytoplasmic, signalling domain. The sensing domain contains a $c$-type haem and the degree of methyllabelling of the signalling domain was found to be influenced by addition of oxygen (decreased labelling) and of the reductant dithionite (increased labelling). Thus DcrA and the 15 other members of the D. vulgaris chemoreceptor family (Deckers \& Voordouw, 1994) may help the organism to find its optimal ecological niche. 
Flucidation of the function of DcrA requires a genetic approach in which the phenotypic change of a targeted gene replacement mutant is assessed relative to the wildtype. Unfortunately, the genetics of the sulfate-reducing bacteria have lagged far behind their physiological and biochemical characterization (Wall, 1993). Conjugal transfer of broad-host-range plasmids belonging to incompatibility group IncQ is presently the only gene transfer method available for D. vulgaris (Argyle et al., 1992; Powell et al., 1989; van den Berg et al., 1989). Attempts to use conjugation of suicide plasmids for construction of specific gene mutants of D. vulgaris were unsuccessful (van den Berg et al., 1989; van Dongen $e t$ al., 1994). The intriguing biochemical properties of DcrA provided a strong incentive to revisit the problem of gene interruption or replacement in D. vulgaris. We report here the replacement of $d c r A$ with a cat gene marker and describe the phenotype effects of this replacement.

\section{METHODS}

Bacterial strains, plasmids and growth conditions. Bacteria and plasmids used in this study are listed in Table 1. Escherichia coli strains were grown at $37^{\circ} \mathrm{C}$ in tryptone/yeast extract (TY) medium or on TY agar plates with antibiotics as required (Voordouw et al., 1989). Liquid cultures of $D$. vulgaris were grown in medium C (Postgate, 1984) at $35^{\circ} \mathrm{C}$ in an anaerobic hood (Forma Scientific) containing a gas mixture of $5 \%(\mathrm{v} / \mathrm{v}) \mathrm{H}_{2}, 10 \%(\mathrm{v} / \mathrm{v}) \mathrm{CO}_{2}$ and $85 \%(\mathrm{v} / \mathrm{v}) \mathrm{N}_{2}$. Strains used for chemotactic studies were first grown on a medium $\mathrm{C}$ swarm plate $(0 \cdot 1 \%, w / v$, agar $)$ to select motile cells and then grown in liquid medium $\mathrm{C}$ or in TY medium overnight before use. Plating and colony purification of $D$. vulgaris was done by spreading diluted liquid cultures (containing approx. 50 c.f.u.) on medium E plates (Postgate, 1984), containing appropriate antibiotics, at $35^{\circ} \mathrm{C}$ in the same gas atmosphere. D. vulgaris strains were stored as liquid cultures in medium B (Postgate, 1984) at $4{ }^{\circ} \mathrm{C}$.

Mating of D. vulgaris with E. coli $\mathrm{S} 17-1$ was done on a medium E plate supplemented with $1.5 \mathrm{~g} \mathrm{KNO}_{3} \mathrm{l}^{-1}$ to allow growth of E. coli in the anaerobic hood (Powell et al., 1989). Integrant selection was on a medium $\mathrm{E}$ plate containing chloramphenicol $\left(\mathrm{Cm} ; 10 \mu \mathrm{g} \mathrm{m}^{-1}\right)$ and kanamycin $(\mathrm{Km}$ $\left.50 \mu \mathrm{g} \mathrm{ml}^{-1}\right)$. These concentrations of antibiotics were used throughout in both liquid cultures and plating media unless otherwise stated. Medium $\mathrm{C}$ or medium E containing $\mathrm{Cm}$ and sucrose $(2.5$ to $10 \%, \mathrm{w} / \mathrm{v})$ were used for enrichment and selection of gene replacement mutants.

Integration plasmid construction. Plasmid pDcr 1 was cut with HindIII and BamHI, and religated after end-filling to remove these sites (Fig. 1). The resulting plasmid was cut with Pst I and MluI, and ligated with a BamHI linker after end-

Table 1. Bacterial strains and plasmids

\begin{tabular}{|c|c|c|}
\hline Strain or plasmid & Relevant genotype and/or phenotype & Reference \\
\hline \multicolumn{3}{|c|}{ Desulfovibrio vulgaris } \\
\hline Hildenborough & NCIMB 8303; wild-type, $\mathrm{Km}^{\mathrm{R}} \mathrm{Cm}^{\mathrm{s}} \mathrm{Suc}^{\mathrm{R}}$ & Postgate (1984) \\
\hline F1 & With $\mathrm{p} \Delta \mathrm{Dcr} A 2 \mathrm{CTB}$ integrated into the chromosome; $\mathrm{Km}^{\mathrm{R}} \mathrm{Cm}^{\mathrm{R}} \mathrm{Suc}^{\mathrm{R}}$ & This study \\
\hline F1SR & All F1 derivatives with $s a c B$ gene mutated; $\mathrm{Km}^{\mathrm{R}} \mathrm{Cm}^{\mathrm{R}} S_{\mathrm{uc}}^{\mathrm{R}}$ & This study \\
\hline $\mathrm{F} 100$ & $\begin{array}{l}d c r A \text { gene replaced with a cat gene cassette from pUC19Cm; } \mathrm{Km}^{\mathrm{R}} \\
\mathrm{Cm}^{\mathrm{R}} \mathrm{Suc}^{\mathrm{R}}\end{array}$ & This study \\
\hline \multicolumn{3}{|l|}{ Escherichia coli } \\
\hline TG2 & $\Delta\left(\right.$ lac-pro) supE thi hsdM hsdR recA $\mathrm{F}^{\prime}\left(\right.$ traD36 proAB $B^{+}$lac $\left.\mathrm{Z} \Delta \mathrm{M} 151^{9}\right)$ & Sambrook et al. (1989) \\
\hline S17-1 & $\begin{array}{l}\text { thi pro hsdR recA with } \mathrm{RP} 4-2[\mathrm{Tc}:: \mathrm{Mu}, \mathrm{Km}:: \mathrm{Tn} 7] \text { in the chromosome; } \\
\text { mobilizer strain }\end{array}$ & Simon et al. (1983) \\
\hline \multicolumn{3}{|l|}{ Plasmid } \\
\hline pDcr1 & pUC8 containing the $d c r A$ gene on a $3.4 \mathrm{~kb} A v a \mathrm{I}-E c o \mathrm{RI}$ fragment; $A \mathrm{p}^{\mathrm{R}}$ & Dolla et al. (1992) \\
\hline pJK9Ava1 & $\begin{array}{l}\text { pUC8 containing the } 5^{\prime} \text { end of the } d c r A \text { gene on a } 1.4 \mathrm{~kb} \text { Aval-EcoRI } \\
\text { fragment; } \mathrm{Ap}^{\mathrm{R}}\end{array}$ & Dolla et al. (1992) \\
\hline pMOB2 & Containing an ori $T-s a c B R$ cassette on a $4.8 \mathrm{~kb}$ Not I fragment; $\mathrm{Km}^{\mathrm{R}}$ & Schweizer (1992) \\
\hline pNOT19 & pUC19 with 10 bp NdeI-NotI adaptor in NdeI site; $\mathrm{Ap}^{\mathrm{R}}$ & Schweizer (1992) \\
\hline pSUP104 & Broad-host-range vector; $\mathrm{Cm}^{\mathrm{R}}$ & Priefer et al. (1985) \\
\hline pUC19 & Cloning vector, $\mathrm{pMB} 1$ origin of replication; $\mathrm{Ap}^{\mathrm{R}}$ & Yanisch-Perron et al. (1985) \\
\hline pUC19Cm & $\begin{array}{l}\text { pUC19 containing in its Bam } \mathrm{HI} \text { site a } 1.4 \mathrm{~kb} \text { SaclI-TthIII fragment } \\
\text { from pSUP104, carrying the cat gene; } \mathrm{Ap}^{\mathrm{R}} \mathrm{Cm}^{\mathrm{R}}\end{array}$ & This study \\
\hline $\mathrm{p} \Delta \mathrm{DcrA} 2$ & $\begin{array}{l}\text { A derivative of } \mathrm{pDcr} 1 \text {, containing the flanking regions of the } d c r A \text { gene } \\
\text { of which the PstI-Mlu I fragment has been replaced with a BamHI } \\
\text { linker; } \mathrm{Ap}^{\mathrm{R}}\end{array}$ & This study \\
\hline $\mathrm{p} \Delta \mathrm{D} \mathrm{cr} A 2 \mathrm{Cm}$ & $\mathrm{p} \triangle \mathrm{DcrA} 2$ with a $c a^{+}$gene inserted at the $B a m \mathrm{HI}$ site; $\mathrm{Ap}^{\mathrm{R}}, \mathrm{Cm}^{\mathrm{R}}$ & This study \\
\hline $\mathrm{p} \Delta \mathrm{Dcr} \mathrm{A} 2 \mathrm{~N}$ & $\mathrm{p} \Delta \mathrm{DcrA} 2$ with the $N d e \mathrm{I}$ site changed to $\operatorname{Not} \mathrm{I} ; \mathrm{Ap}^{\mathrm{R}}$ & This study \\
\hline $\mathrm{p} \Delta \mathrm{Dcr} \mathrm{A} 2 \mathrm{CmN}$ & $\mathrm{p} \Delta \mathrm{Dcr} \mathrm{A} 2 \mathrm{~N}$ with a cat gene inserted at the BamHI site; $\mathrm{Ap}^{\mathrm{R}}, \mathrm{Cm}^{\mathrm{R}}$ & This study \\
\hline $\mathrm{p} \Delta \mathrm{Dcr} A 2 \mathrm{CTB}$ & $\begin{array}{l}\text { A mobilizable derivative of } \mathrm{p} \triangle \mathrm{Dcr} \mathrm{A} 2 \mathrm{CmN} \text { containing an oriT-sacBR } \\
\text { cassette from pMOB2 in the NotI site; } \mathrm{Ap}^{\mathrm{R}} \mathrm{Cm}^{\mathrm{R}} \mathrm{Suc}^{\mathrm{s}}\end{array}$ & This study \\
\hline
\end{tabular}




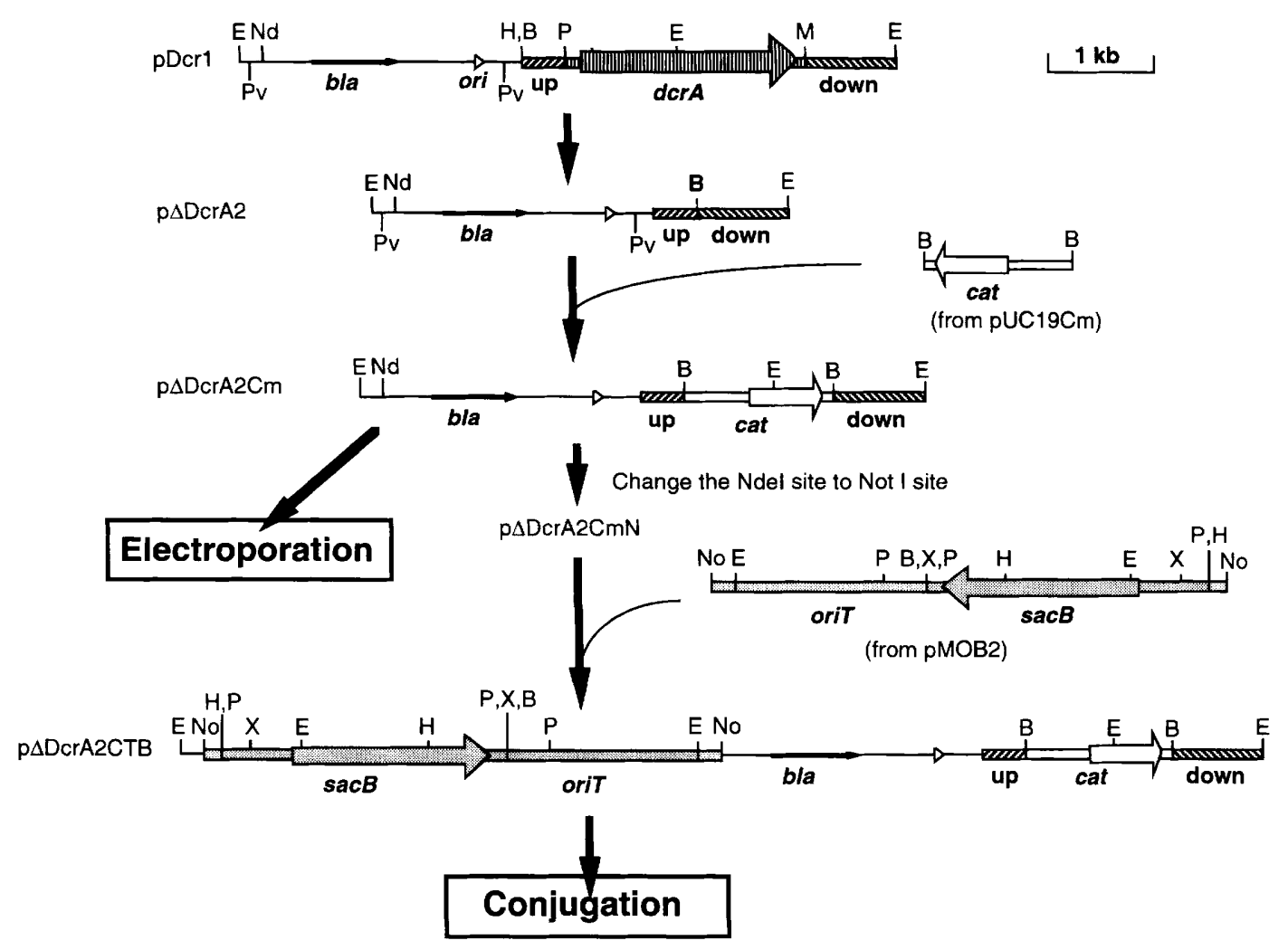

\begin{abstract}
Fig. 1. Construction of integration plasmids $p \triangle D c r A 2 C m$ and $p \triangle D c r A 2 C T B$. The thin line indicates $D N A$ from pUC vector; bla, gene for $\beta$-lactamase; ori, pMB 1 origin of replication (functional in $E$. coli only). The hatched boxes indicate DNA of the target gene region of $D$. vulgaris: 'up' and 'down', DNA upstream and downstream from the dcrA gene. The cat gene from pUC $19 \mathrm{Cm}$ is indicated, as well as the Notl cartridge from pMOB2 containing the origin for conjugal transfer (oriT) and the counter-selectable gene sacB from B. subtilis. Relevant restriction sites are: B, BamHI; E, EcoRI; H, HindlII; M, Mlul; Nd, Ndel; No, Notl; P, Pstl; Pv, Pvull; X, Xbal.
\end{abstract}

repair to form $\mathrm{p} \triangle \mathrm{DcrA} 2$ (Fig. 1). A $1.4 \mathrm{~kb} \mathrm{BamHI}$ fragment from pUC19Cm was then ligated to the BamHI site of $\mathrm{p} \Delta \mathrm{Dcr} A 2$ to form $\mathrm{p} \Delta \mathrm{DcrA} 2 \mathrm{Cm}$. This plasmid was used directly, or after linearization with NdeI, for transformation of $D$. vulgaris by electroporation. For construction of the integration plasmid $\mathrm{p} \Delta \mathrm{Dcr} \mathrm{A} 2 \mathrm{CTB}, \mathrm{p} \Delta \mathrm{DcrA} 2$ was cut with $P v u I I$, and the $2.4 \mathrm{~kb}$ vector fragment replaced with the equivalent PvuII fragment of pNOT19 to generate $\mathrm{p} \Delta \mathrm{Dcr} A 2 \mathrm{~N}$. The $B a m H I$ fragment from pUC19Cm was next inserted to form $\mathrm{p} \triangle \mathrm{Dcr} A 2 \mathrm{CmN}$, followed by insertion of the $4.8 \mathrm{~kb}$ NotI cassette to give $\mathrm{p} \Delta \mathrm{D}$ crA2CTB (Fig. 1). After confirmation that the inserted $s a c B$ was functional in an $E$. coli strain containing this plasmid, it was used for conjugal transfer from E. coli S171 to $D$. vulgaris.

Transformation of $D$. vulgaris by electroporation. Plasmids p $\triangle$ DcrA2Cm, pSUP104 prepared from E. coli, and pSUP104 prepared from $D$. vulgaris were used for transformation of $D$. vulgaris by electroporation as described by Rousset $e t$ al. (1991). A $100 \mathrm{ml}$ culture of D. vulgaris, grown in medium C to $\mathrm{OD}_{600} 0 \cdot 4$, was suspended in a final volume of $200 \mu \mathrm{l}$. A $35 \mu \mathrm{l}$ aliquot of this cell preparation and $3 \mu \mathrm{l}$ DNA $(1-2 \mu \mathrm{g})$ were transferred into an electroporation cuvette (Bio-Rad), and subjected to electric pulses $(2.5 \mathrm{kV}, 25 \mathrm{mF}$ and $400-1000 \Omega)$ in a Gene Pulser (Bio-Rad); $1 \mathrm{ml}$ SOC buffer (Dower et al., 1988) was added to the cuvette immediately and the cell mixtures were allowed to recover at $35^{\circ} \mathrm{C}$ for $1 \mathrm{~h}$. Aliquots of $200 \mu \mathrm{l}$ were then plated onto medium E plates containing $\mathrm{Cm}$. The plates were incubated for 3 to $7 \mathrm{~d}$. TE buffer $(10 \mathrm{mM}$ Tris $/ \mathrm{HCl}, \mathrm{pH} 7 \cdot 4,1 \mathrm{mM}$ EDTA) replaced the DNA sample in negative controls.

Conjugal transfer and selection for plasmid integration. E. coli mobilizer strain S17-1 transformants were used as the donor for conjugal transfer of the integration plasmid $\mathrm{p} \triangle \mathrm{DcrA2CTB}$ (Fig. 2, $\mathrm{p} \Delta$ ) into recipient D. vulgaris using a filter mating method adapted from Powell et al. (1989). Plasmid pSUP104 was similarly transferred to determine the conjugation efficiency. Overnight cultures of D. vulgaris in medium $C(1 \mathrm{ml})$ and E. coli donor cells $(0.2 \mathrm{ml})$ were mixed in a $1.5 \mathrm{ml}$ microfuge tube under anaerobic conditions. After centrifugation the cell mixture was resuspended in $20 \mu \mathrm{l}$ medium C, and spread onto a membrane filter (Millipore-MF, $0.22 \mu \mathrm{m}$; diameter $25 \mathrm{~mm}$ ) placed on a medium $\mathrm{E} /$ nitrate mating plate. Following anaerobic incubation for $1 \mathrm{~d}$ the filter was transferred to a microfuge tube and the cells resuspended in $1 \mathrm{ml}$ medium C. Aliquots $\left(10 \mu \mathrm{l}\right.$, approx. $10^{7} \mathrm{D}$. vulgaris cells, for transfer of $\mathrm{p} \Delta \mathrm{DcrA2CTB} ; 20 \mu \mathrm{l} 10^{-4}$ dilution for transfer of pSUP104) were plated onto medium $\mathrm{E}$ plates containing $\mathrm{Km}$ and $\mathrm{Cm}$. These were incubated for 5 to $7 \mathrm{~d}$ and the $\mathrm{Cm}^{\mathrm{R}}$ colonies that emerged were restreaked and analysed by Southern hybridization to verify and map plasmid integration.

Sucrose sensitivity assays. Aliquots $(1 \mathrm{ml})$ of fresh, saturated cultures of colony-purified integrants were inoculated 
$\mathbf{p} \Delta$
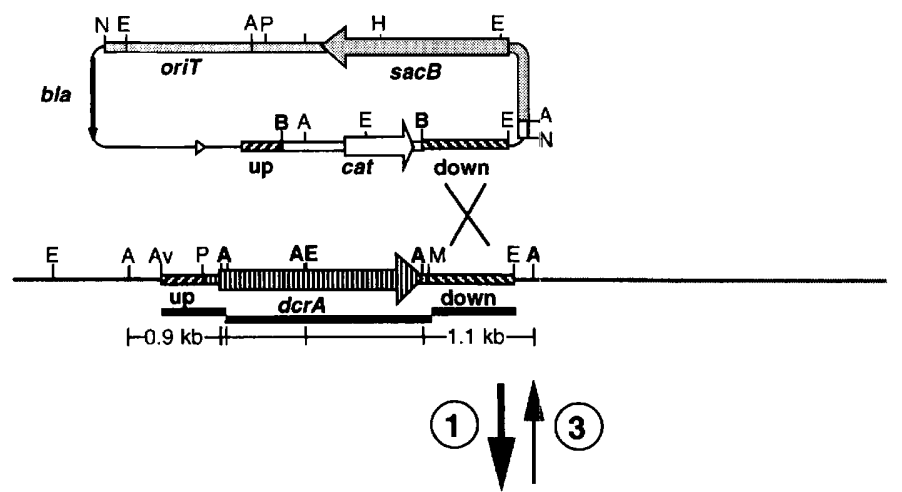

F1

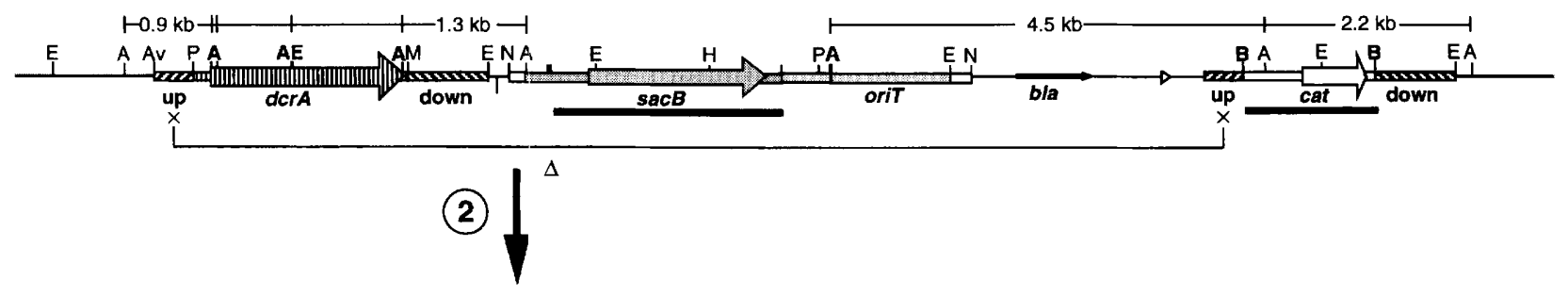

F100

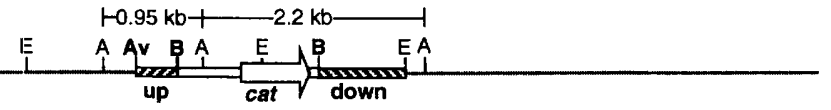

Fig. 2. Strategy used for gene-replacement mutagenesis of dcrA in $D$. vulgaris Hildenborough through conjugation. Maps of the suicide integration plasmid $\mathrm{p} \triangle \mathrm{Dcr} A 2 \mathrm{CTB}(\mathrm{p} \Delta)$, and the dcrA target gene region in $D$. vulgaris wild-type (wt), the plasmid integrant $D$. vulgaris $F 1(F 1)$, and the desired gene-replacing second recombination product $D$. vulgaris $F 100$ (F100) are shown with symbols for genes the same as in Fig. 1. The same restriction sites are indicated as in Fig. 1, as well as A, Accl and Av, Aval. The DNA regions used as probes in Figs 3, 5 and 6 (thick lines beneath the wt and F1 map), and the sizes of the relevant $A c c l$ fragments, are also indicated. The homologous recombinations $(x)$ are indicated as: (1), plasmid integrative recombination; (2), gene-replacing, second recombination; (3), reversing, abortive recombination.

anaerobically into screw-capped glass tubes (external diameter $13 \mathrm{~mm}$ ) containing $5 \mathrm{ml}$ medium $\mathrm{C}$ with $\mathrm{Cm}$. Two tubes were inoculated for each culture and growth was monitored with a Klett meter. After $3 \mathrm{~h}, 0.67 \mathrm{ml} 50 \%(\mathrm{w} / \mathrm{v}$ ) sucrose was added anaerobically into one of the two tubes. The cell density of both tubes was then monitored regularly for $2 \mathrm{~d}$.

Selection and enrichment of deletion mutants. Liquid enrichment of $\mathrm{Cm}^{\mathrm{R}} \mathrm{Suc}^{\mathrm{R}}$ cells was done by inoculating 5 to $10 \mu \mathrm{l}$ of the integrant culture into $5 \mathrm{ml}$ medium $\mathrm{C}$ with $\mathrm{Cm}$ and sucrose $(2 \cdot 5-10 \%, \mathrm{w} / \mathrm{v})$ and growing anaerobically for 7 to $9 \mathrm{~d}$ until saturation. Chromosomal DNA was prepared from these cultures and analysed by Southern blotting. Cultures containing the desired $d c r A$ deletion were next subjected to colony purification on medium E plates with $\mathrm{Cm}$, and DNAs obtained from liquid cultures of isolated colonies were again screened by Southern blot analysis.

Southern blot analysis. Chromosomal DNA of D. vulgaris was isolated by a mini-preparation protocol adapted from Marmur (1961), using 1.5 to $5 \mathrm{ml}$ cultures. For verification of plasmid integration, undigested chromosomal DNA was run on an agarose gel and blotted onto a Hybond-N nylon membrane (Amersham). The blot was probed with ${ }^{32} \mathrm{P}-$ labelled cat gene DNA, obtained as a $1.4 \mathrm{~kb}$ fragment from plasmid pUC19Cm. This targets the region indicated for the integrant strain F1 in Fig. 2 (F1, cat). For the integration mapping and identification of the gene-replacing second recombination, chromosomal DNA was digested to completion with AccI or EcoRI before agarose gel electrophoresis and blotting. The blots were analysed by hybridization with ${ }^{32}$ P-labelled DNA probes of the $d c r A$ gene flanking regions: the $A v a \mathrm{I}-K p n \mathrm{I}$ region upstream from the $d c r A$ gene and the $M l u \mathrm{I}-E c o$ RI region downstream from the $d c r A$ gene (Fig. 2, wt, 'up' and 'down'), obtained as $0.58 \mathrm{~kb} B a m \mathrm{HI}-K p n \mathrm{I}$ and $0.9 \mathrm{~kb} \mathrm{BamHI}-E c o$ RI fragments from plasmids pJK9Aval and $\mathrm{p} \Delta \mathrm{Dcr} \mathrm{A} 2$, respectively. The blots were then stripped of these probes, and re-probed with ${ }^{32} \mathrm{P}$-labelled $d c r A$ gene (Fig. 2, wt, $d c r A$ ), obtained as a $2.0 \mathrm{~kb} \mathrm{KpnI-MluI} \mathrm{fragment} \mathrm{from} \mathrm{plasmid}$ pDcr1, to confirm the absence of $d c r A$. In addition, a ${ }^{32} \mathrm{P}$ labelled $s a c B$ gene (Fig. 2, F1, sacB), obtained as a $2.4 \mathrm{~kb} \mathrm{XbaI}$ fragment from pMOB2, was used as a probe for analysing deletion and insertion mutations of the $s a c B$ gene. All the above Southern hybridizations were performed under highly stringent conditions as described elsewhere (Sambrook et al., 1989).

Growth properties and stability of the $D$. vulgaris F100 strain. The $\Delta d c r A$ strain, D. vulgaris F100, and the wild-type were grown separately in medium $C$ in screw-capped tubes and their growth curves were determined by measuring the change in cell density with time using a Klett meter. For assessment of competitiveness under anaerobic conditions the F100 strain was co-cultured with the wild-type in medium $\mathrm{C}$ without $\mathrm{Cm}$. Following mixing, a $5 \%$ inoculum was used and allowed to grow for 1-2 d before the next transfer. Chromosomal DNAs were prepared from a portion of the initial mixture of the two strains and from each of the subsequent co-cultures. The chromosomal DNAs were restricted with EcoRI, and the 
digests were analysed by agarose gel electrophoresis and Southern blot hybridization with the downstream region probe to assess changes in the ratio of F100 to wild-type DNA.

For assaying the differential stability under aerobic conditions, fresh cultures of F100 and wild-type were mixed at a ratio of $1: 1$ or $1: 2(\mathrm{v} / \mathrm{v})$, and $1.5 \mathrm{ml}$ of these mixtures was diluted immediately with $50 \mathrm{ml}$ medium $\mathrm{C}$, which was prepared aerobically and contained resazurin $\left(0.5 \mathrm{mg} \mathrm{l}^{-1}\right)$ as redox indicator. The diluted cell mixtures were then incubated aerobically in $500 \mathrm{ml}$ Erlenmeyer flasks at $37^{\circ} \mathrm{C}$ with vigorous shaking for up to $6 \mathrm{~h}$. Aliquots of $1.5 \mathrm{ml}$ were taken at different times and moved immediately into the anaerobic hood. To each of these samples, 30 to $60 \mu \mathrm{l} 115 \mathrm{mM} \mathrm{Na}_{2} \mathrm{~S}_{2} \mathrm{O}_{4}$ solution was added until the light blue colour disappeared. The samples were then re-grown anaerobically at $35^{\circ} \mathrm{C}$ to saturation. Chromosomal DNAs were prepared from each of the re-grown samples to determine the ratio of the two strains by Southern blot analysis.

Determination of the anaerotactic phenotype. The anaerotactic behaviour of D. vulgaris $\mathrm{F} 100$ and wild-type was assessed by microchamber and capillary tube assays. The microchamber was made of a glass microscope slide and a coverslip $(60 \times 25 \mathrm{~mm}, 0 \cdot 17 \mathrm{~mm}$ thick) separated with two narrow strips of a coverslip as spacers between them and sealed with nail-polishing solution along the longer axis to form a rectangular flattened chamber with two open ends. Motile cell samples in medium C or TY medium were transferred out of the anaerobic hood in capped microfuge tubes before use. About $100 \mu \mathrm{l}$ of the anaerobic preparation of motile cells was transferred into the microchamber with a pipette to form a continuous liquid phase along the chamber with a liquid-air interface at both ends. The aerotactic behaviour of motile cells near the liquid-air interface was then examined under a Nikon Labophot light microscope with dark-field illumination.

The capillary tube assay was used to examine the effect of changing the gas phase on cell migration near the medium-gas interface. Micro-measuring capillary tubes $(20 \mu \mathrm{l}$ capacity, $100 \mathrm{~mm}$ long; Fisher, catalogue no. 21-164-2D) were autoclaved before use. Two capillary tubes were filled anaerobically with a $5 \mathrm{~cm}$ long column of a motile cell preparation of $D$. vulgaris wild-type or $F 100$ by the capillary effect and sealed at the medium phase end with Plasticine (Canada Games Company). Both tubes were then moved out of the anaerobic hood and exposed to air to allow anaerotactic banding of the cells. The tubes were then lined up and loosely connected to a rubber tubing leading to the gas cylinders (either nitrogen or oxygen; Fig. 7a). A gas humidifier containing water was added to the gas line to prevent sample evaporation. Anaerotactic behaviour was examined either visually or with the Nikon Labophot light microscope, which had a narrow slit light stop inserted into the light path to alter the illumination for better visualization of bacteria in the round-shaped capillary tubes.

Northern blot analysis. The effect of deletion of the $d c r A$ gene on transcription of the rbo-rub operon was investigated by Northern blot assays. D. vulgaris wild-type and F100 were grown in $12 \mathrm{ml}$ medium C overnight. Aliquots of $2 \mathrm{ml}$ of these cultures were transferred to 12 culture tubes, which were moved out of the anaerobic hood. One sample of each strain was used immediately for total RNA preparation. The others were exposed to oxygen by shaking in air at 300 r.p.m. Total RNA was extracted from each sample with a rapid isolation protocol (Reddy \& Gilman, 1990). The total RNA preparations were analysed by Northern hybridization
(Brown, 1990). Following electrophoresis the gel was stained with ethidium bromide and photographed to ascertain equality of RNA loading from the intensities of the bands for 23S, $16 \mathrm{~S}$ and $5 \mathrm{~S}$ rRNA. The RNA was then transferred to a Hybond-N membrane and hybridized with the ${ }^{32} \mathrm{P}-$ labelled insert of plasmid pRbo1 (Brumlik \& Voordouw, 1989). Following washing the blot was exposed to the phosphorimaging plate of a Fuji BAS1000 BioImaging Analyzer for quantification of rbo-rub mRNA.

\section{RESULTS}

\section{Electroporation of $D$. vulgaris}

Electroporation of $D$. vulgarius with circular or linearized $\mathrm{p} \Delta \mathrm{D} c r \mathrm{~A} 2 \mathrm{Cm}$ failed to give $\mathrm{Cm}^{\mathrm{R}}$ transformants. Electroporation of the broad-host-range vector pSUP104 isolated from $E$. coli also failed to give $\mathrm{Cm}^{\mathrm{R}}$ transformants, although they could be readily obtained by conjugation (van den Berg et al., 1989; this work, Table 2). The results indicated either that $D$. vulgaris is not readily transformed by electroporation or that a restiction barrier prevents the establishment of foreign DNA. In order to distinguish between these two possibilities, we isolated native pSUP104 from a D. vulgaris transconjugant. Electroporation of this native pSUP104 gave approximately $10^{3}$ transformants per $\mu \mathrm{g}$ DNA, while no transformants were obtained upon electroporation of $E$. coli pSUP104 under the same conditions. This result suggested that a restriction/methylation system in D. vulgaris prevents the establishment of foreign DNA transferred by electroporation. We therefore resorted to the conjugal transfer approach in which the DNA being transferred is not as susceptible to host restriction (Schweizer, 1992).

\section{Conjugal transfer and integration of a suicide plasmid}

Plasmid $\mathrm{p} \Delta \mathrm{D} \operatorname{cr} \mathrm{A} 2 \mathrm{CTB}$ was transferred by conjugation from E. coli $\mathrm{S} 17-1$ to $D$. vulgaris. A positive control [mating with E. coli S17-1(pSUP104)], and a negative control (mating with nontransformed E. coli S17-1) were also done. Following spreading of the mating mixtures onto medium $\mathrm{E}$ plates containing $\mathrm{Km}$ and $\mathrm{Cm}$, pSUP104 transconjugants appeared after $3 \mathrm{~d}$ while $\mathrm{p} \Delta \mathrm{Dcr} \mathrm{A} 2 \mathrm{CTB}$ integrants (D. vulgaris $\mathrm{F} 1$ ) were obtained at a frequency of $1 \cdot 1 \times 10^{-7}$ per recipient after $4-5 \mathrm{~d}$ anaerobic growth (Table 2 ). No colonies appeared in plates spread with the negative control mating mixture. Integration of the suicide plasmid was verified by hybridization of the cat gene probe to the undigested chromosomal DNA (data not shown). Chromosomal DNAs from two of the integrants were further analysed. Digestion with $A c c \mathrm{I}$ and hybridization with the flanking region probes gave 0.9 and $1.1 \mathrm{~kb}$ fragments for $D$. vulgaris wild-type (Fig. 3, lane 2). In the two integrants the $1.1 \mathrm{~kb}$ fragment was missing and three new hybridization bands appeared (Fig. 3, lane 3: 1·3, 2.2 and $4.5 \mathrm{~kb}$ ), indicating that these two integrants were identical, with integration of $\mathrm{p} \triangle \mathrm{Dcr} A 2 \mathrm{CTB}$ through the downstream region of $d c r A$ as illustrated in Fig. 2(1)). 
Table 2. Results of conjugal transfer and selection of integrants

\begin{tabular}{|lcccc|}
\hline $\begin{array}{l}\text { Plasmid } \\
\text { for transfer }\end{array}$ & $\begin{array}{c}\text { Growth time* } \\
\text { (d) }\end{array}$ & $\begin{array}{c}\text { Apparent conjugal } \\
\text { transfer frequency } \\
\text { (no. of transconjugants } \\
\text { per recipient cell) }\end{array}$ & $\begin{array}{c}\text { Apparent } \\
\text { integration frequency } \\
\text { (no. of integrants } \\
\text { per recipient cell) }\end{array}$ & $\begin{array}{c}\text { Integration frequency } \\
\text { (no. of integrants } \\
\text { per transconjugant cell) }\end{array}$ \\
\hline pSUP104 & 3 & $2 \cdot 3 \times 10^{-2} \ddagger$ \\
p $\triangle \mathrm{D}$ crA2CTB & $4-5$ & ND & NA & NA \\
\hline
\end{tabular}

ND, Not determined; NA, not applicable.

* Time required for appearance of $\mathrm{Cm}^{\mathrm{R}}$ colonies on plates containing $10 \mu \mathrm{g} \mathrm{Cm} \mathrm{m}^{-1}$.

†Estimated by dividing the number of integrants per recipient cell of $\mathrm{p} \Delta \mathrm{DcrA2CTB}$ by the number of transconjugants per recipient cell of pSUP104.

$\ddagger$ Result is the mean of four experiments.

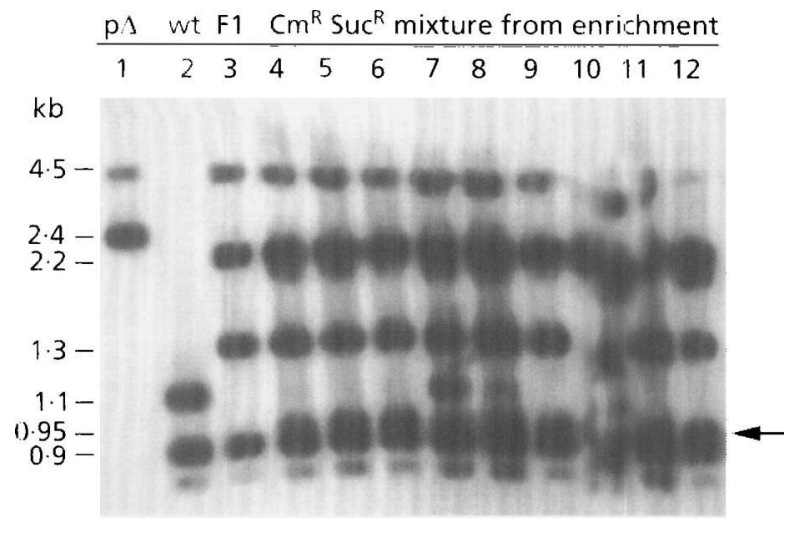

Fig. 3. Southern blot analysis of integration plasmid $\mathrm{p} \triangle \mathrm{DcrA2CTB}$ (lane 1), genomic DNA of $D$. vulgaris Hildenborough (lane 2), D. vulgaris F1 (lane 3), and enrichment cultures (lanes 4 to 12 ) in medium $C$ with $10 \mu \mathrm{g} \mathrm{Cm} \mathrm{ml}^{-1}$ and $2.5 \%$ (lanes 4,7 and 10 ), $5 \%$ (lanes 5,8 and 11 ) or $10 \%$ (lanes 5,9 and 12) sucrose. The DNA samples were restricted with Accl, and the blot was hybridized with the 'up' and 'down' probes shown in Fig. 2. Sizes of the relevant Accl fragments are indicated on the left. The arrow indicates the $0.95 \mathrm{~kb} A \mathrm{ccl}$ fragment which is diagnostic for the gene-replacement product D. vulgaris F100.

This integrant, D. vulgaris F1, was used for further manipulation.

\section{Effect of sucrose and $\mathrm{Cm}$ on the growth of $D$. vulgaris $\mathrm{F} 1$}

Cm up to $10 \mu \mathrm{g} \mathrm{ml}^{-1}$ had no severe effects on growth of F1. However, in the presence of both sucrose and chloramphenicol the cell density decreased significantly after one generation (Fig. 4), indicating the occurrence of cell lysis. Addition of sucrose to wild-type D. vulgaris samples had no such effect. These results indicated that the $s a c B$ gene was expressed in D. vulgaris $\mathrm{F} 1$ and that its

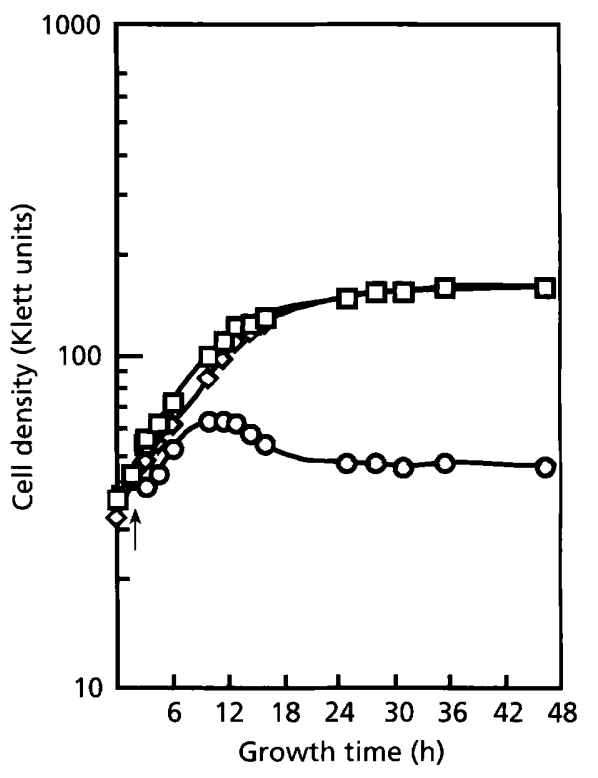

Fig. 4. Sucrose sensitivity of the integrant strain $D$. vulgaris $F 1$. Cells were grown anaerobically at $35^{\circ} \mathrm{C}$ in medium $\mathrm{C}(\square)$, medium $C$ with $10 \mu \mathrm{g} \mathrm{Cm} \mathrm{ml}^{-1}(\diamond)$, or medium $\mathrm{C}$ with $\mathrm{Cm}$ and $5 \%(\mathrm{~W} / \mathrm{v})$ sucrose $(O)$. The sucrose was added at the time indicated by the arrow. Cell densities in Klett units are plotted versus time in hours.

product, levansucrase, was toxic to $D$. vulgaris in the presence of sucrose, as has been demonstrated in E. coli (Steinmetz et al., 1983), allowing $s a c B$ to be used as a counter-selectable marker to select for the rare, genereplacing, second recombination (Fig. 2, (2)).

Use of $10 \mu \mathrm{g} \mathrm{Cm} \mathrm{ml}^{-1}$ in both liquid and agar media was found to be the appropriate concentration to select $D$. vulgaris F1 from the wild-type. D. vulgaris $\mathrm{F} 1$ grew and maintained high plating efficiency, while the wild-type did not grow provided that a cell density of no more than $10^{5}$ cells $\mathrm{cm}^{-2}$ was used for plating and that no 
more than $10^{7}$ cells $\mathrm{ml}^{-1}$ ( $1 \%$ inoculum) was used for liquid culture. Hence, $\mathrm{Cm}$ at $10 \mu \mathrm{g} \mathrm{ml}^{-1}$ and a limited volume of inoculum were used in combination with sucrose in the next step to select for conversion of D. vulgaris $\mathrm{F} 1$ to the gene replacement mutant F100 and against conversion to wild-type resulting from plasmid excision.

\section{Sucrose and $\mathrm{Cm}$ enrichment of the gene-replacing second recombination}

D. vulgaris $\mathrm{F} 1$ was first grown to saturation in liquid medium $\mathrm{C}$ containing $\mathrm{Cm}$ to allow more recombination events to happen (Fig. 2, (2) prior to selection of the desired D. vulgaris F100. Small inocula $(0 \cdot 1$ to $0 \cdot 2 \%$, $\mathrm{v} / \mathrm{v}$ ) in medium $\mathrm{C}$ with $\mathrm{Cm}$ and sucrose (Suc) were then grown to saturation in $7 \mathrm{~d}$. Genotypic changes in the population were identified by Southern blot analysis. Deletion of $\operatorname{dcr} A$ was expected to change the Accl fragment size, hybridizing with the 'up' probe, from 0.9 and $4.5 \mathrm{~kb}$ in F1 to $0.95 \mathrm{~kb}$ in F100 (Fig. 2) and a variable fraction of this F100-specific band was found after the enrichment (Fig. 3, lanes 4 to $12: 30$ to $100 \%$ of the total population). The rest of the population showed mainly the pattern expected for D. vulgaris F1 and occasionally that of the wild-type. Sucrose concentrations of $2 \cdot 5,5$ and $10 \%(\mathrm{w} / \mathrm{v})$ were all found to be effective in enrichment of the desired gene-replacing second recombination.

After plating one of the enriched cultures on a medium E plate containing $\mathrm{Cm}, 117$ colonies were obtained. From this plate 30 colonies were randomly selected and grown to saturation in medium $\mathrm{C}$ with $\mathrm{Cm}$. Southern blot analysis of their chromosomal DNAs with the $d c r A$ flanking region probes indicated 14 of these to have the restriction pattern expected for the $\operatorname{dcr} A$ gene deletion strain D. vulgaris F100 (Fig. 5a, lanes 3, 5,7, 8 and 10). The remainder had the same restriction pattern as the D. vulgaris F1 control (Fig. 5a, lanes 4, 6, 9 and 11). Deletion of the $d c r A$ gene was proven unambiguously by stripping the blot shown in Fig. 5(a) of the flanking region probes and re-hybridizing with a $d c r A$ probe (Fig. 5b). D. vulgaris F100 clearly lacks the dcrA gene (Fig. 5b, lanes 3,5,7,8 and 10) which is present in the wild-type (Fig. 5b, lane 1), D. vulgaris F1 (lane 2), and the remaining $\mathrm{Cm}^{\mathrm{R}} \mathrm{Suc}^{\mathrm{R}}$ strains denoted $D$. vulgaris F1SR (Fig. 5b, lanes 4, 6, 9 and 11). The $\Delta d c r A$ strain $D$. vulgaris $\mathrm{F} 100$ is cat-gene marked $\left(\mathrm{Cm}^{\mathrm{R}}\right)$ but was stable without $\mathrm{Cm}$ selection.

\section{Inactivation of $\operatorname{sac} B$ by an IS element}

The possibility that the $D$. vulgaris F1SR strains harboured a modified $s a c B$ gene was investigated by stripping and re-probing the blots with the $s a c B$ gene probe. While, as expected, none of the $14 \Delta d c r A$ strains (D. vulgaris F100) showed hybridization to the sacB probe (Fig. 5c, lanes 3, 5, 7, 8 and 10), all of the $16 \mathrm{D}$. vulgaris F1SR strains showed the hybridization, as did their parent $D$. vulgaris $F 1$, indicating that none of these
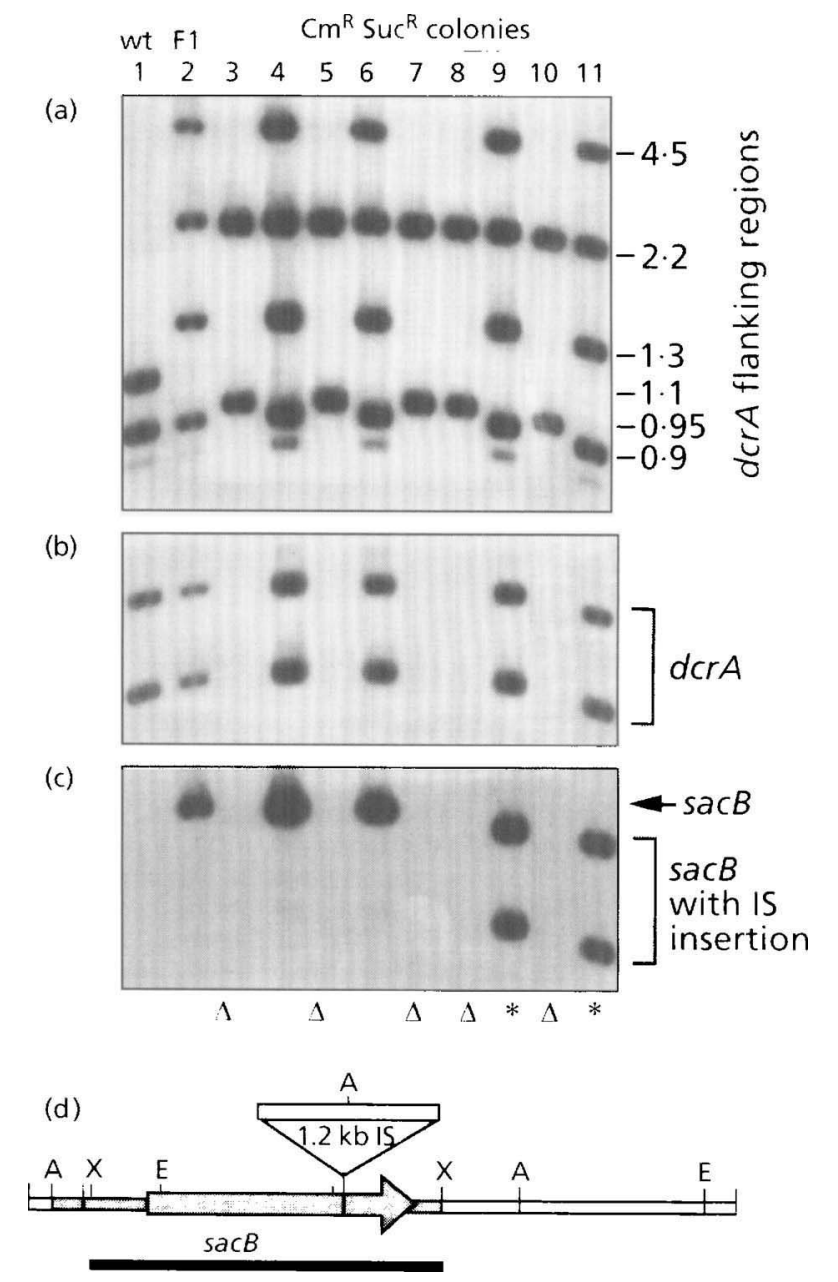

Fig. 5. Southern blot analysis of DNA from $\mathrm{Cm}^{\mathrm{R}}$ Suc ${ }^{\mathrm{R}}$ colonies of $D$. vulgaris. Chromosomal DNAs from $D$. vulgaris wild-type (lane 1), F1 (lane 2), and colony-purified $\mathrm{Cm}^{R}$ Suc ${ }^{R}$ variants (lanes 3 to 11) were restricted with $A C C l$, and the blot was probed with: (a) the up-down probe to identify the desired second recombination products, (b) the $d c r A$ probe to confirm deletion of $d c r A$, and (c) the $s a c B$ probe to identify insertional inactivation of the $\operatorname{sac} B$ gene. The blot was stripped prior to incubation with each new probe. Sizes of the hybridizing genomic DNA fragments are indicated in $\mathrm{kb}$. The clones showing the predicted pattern of $D$. vulgaris F100 $(\Delta)$ and clones showing is element insertion in $\operatorname{SaCB}\left({ }^{*}\right)$ are indicated. (d) Map indicating a $1.2 \mathrm{~kb}$ IS element insertion in the $\operatorname{sac} B$ gene, explaining the hybridization patterns in (c), lanes 9 and 11.

became sucrose-resistant by plasmid excision. Among these 16 D. vulgaris F1SR strains, 10 gave a $3 \cdot 1 \mathrm{~kb} \mathrm{sacB}-$ hybridizing $A c c$ I fragment (Fig. 5c, lanes 4 and 6) as did the parent F1 (lane 2), while six of them displayed two Accl fragments with a combined size of $4.3 \mathrm{~kb}$ (Fig. $5 \mathrm{c}$, lanes 9 and 11), indicating an insertion of a $1.2 \mathrm{~kb}$ DNA element with one $A c c$ I site (Fig. 5d). Cloning and sequencing of the modified $s a c B$ gene from one of these D. vulgaris F1SR strains has indicated that the $1.2 \mathrm{~kb}$ fragment is a novel IS element of D. vulgaris (unpublished). 

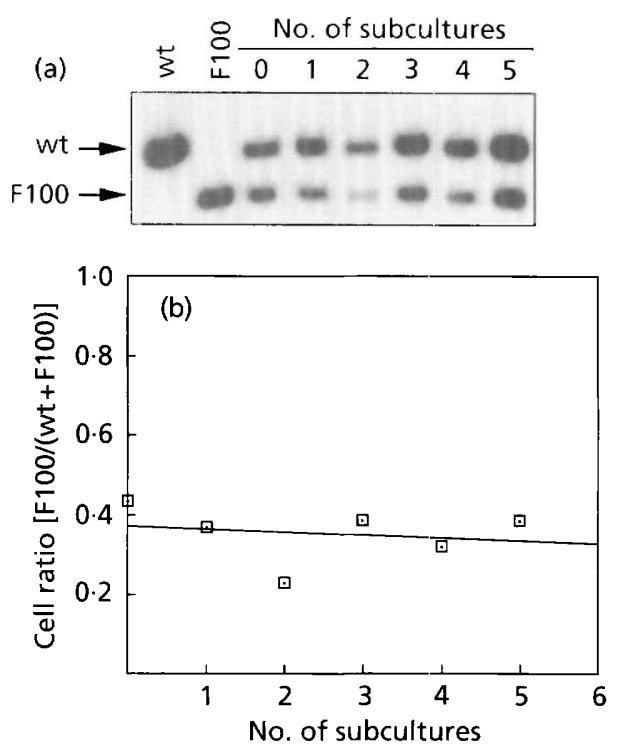
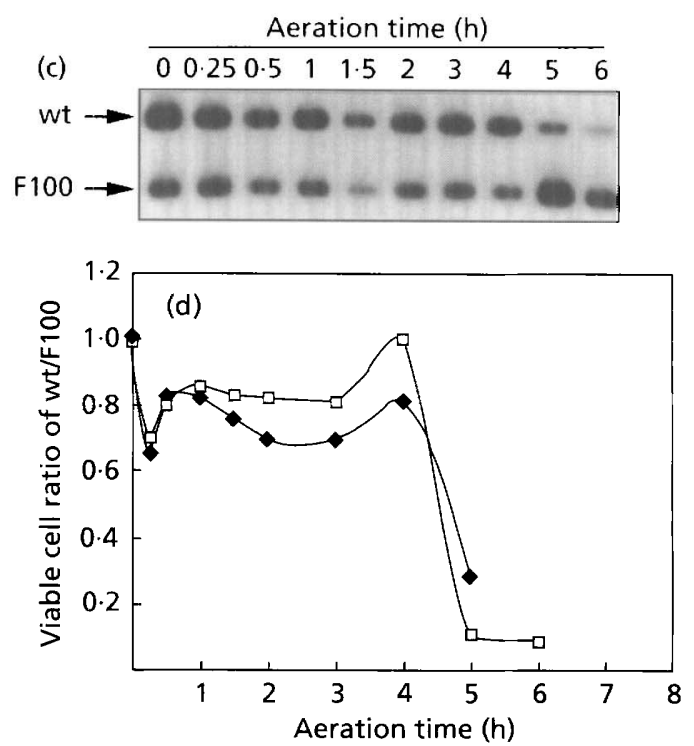

Fig. 6. Stability and oxygen sensitivity of the $\triangle d c r A$ strain $D$. vulgaris F100. (a) Southern blot analysis of chromosomal DNAs from D. vulgaris wild-type (wt), F100, and a mixed culture of wild-type and F100 grown continuously in medium $C$ without $\mathrm{Cm}$ under anaerobic conditions. The number of subcultures of the mixture is indicated above each sample lane. (b) Ratio of F100 to the total population determined by densitometry of the autoradiogram in (a), plotted against subculture number. (c) Southern blot analysis of chromosomal DNAs from a mixed culture of wild-type and F100 in a ratio of 2:1 that was continuously aerated for up to $6 \mathrm{~h}$. The sampling times are indicated above the sample lanes. (d) Ratio of recovered wild-type to F100 cells, determined by densitometry and normalized to 1.0 for time zero, plotted against aeration time. Data are for the autoradiogram in (c) with an initial ratio of wild-type to F100 of 2:1 ( $\square$ ) and for an experiment of which the initial ratio was $1: 1$ ( $\bullet$; autoradiogram not shown). The DNAs were restricted with EcoRI, and both blots were hybridized with the downstream region probe (Fig. 2 ).

\section{Changes in oxygen sensitivity of $D$. vulgaris F100 vs wild-type}

The growth curve of the F100 strain was identical to that of the wild-type (data not shown), confirming that $\operatorname{dcr} A$ is not essential for growth under anaerobic conditions. This was also shown in three differential growth experiments in which the wild-type and F100 were cocultured. The chromosomal DNA ratio of F100 to wildtype remained the same after five sequential subcultures in $7 \mathrm{~d}$, approximately 25 generations (Fig. 6a, b), indicating that F100 was as competitive as the wildtype under anaerobic growth conditions without $\mathrm{Cm}$ selection.

To allow the determination of small differences in oxygen sensitivity, a mixture of the two strains was aerated to ensure that both strains received identical aeration treatment. Survival of wild-type vs F100 was determined by restoring anaerobic conditions and by regrowing the diluted samples to saturation before the genomic DNA ratio of the two strains was determined by Southern blot analysis. As shown in Fig. 6(c,d), exposure of a wild-type-F100 mixture to oxygenated medium $C$ resulted in a significant decrease of the ratio of recovered wild-type to F100 cells after $5 \mathrm{~h}$. The same results were obtained with different initial mixing ratios. Even when twice as many wild-type as F100 cells were used, the ratio of recovered wild-type to F100 cells decreased (Fig. 6d), indicating that the $d c r A$ deletion strain F100 is more resistant to inactivation by aeration than the wild-type.

\section{Anaerotaxis behaviour}

Anaerotactic movement of $D$. vulgaris, defined as movement away from a liquid-air interface, was first observed by Johnson et al. (1995), who suggested that positive aerotaxis (movement towards a liquid-air interface) may also be present, causing the cells to concentrate at an optimal, low oxygen concentration. Motile cells of $D$. vulgaris near the medium-air interface of the microchamber also moved towards the inner area, leaving a clear zone and forming a dense band of cells (not shown). This banding effect was observed for both D. vulgaris wild-type and F100. To confirm that this behaviour was due to anaerotaxis, capillary assays were conducted. When a capillary filled anaerobically with a motile cell preparation was opened to the air, the banding appeared within $20 \mathrm{~min}$ about $2 \mathrm{~mm}$ away from the liquid-air interface. The position shifted further away from the interface with time. No banding was observed in control capillaries which were protected from exposure to air, either by keeping them inside the anaerobic hood or by sealing them anaerobically with petroleum jelly before transfer. These results indicate that band formation was air-dependent. In capillary 

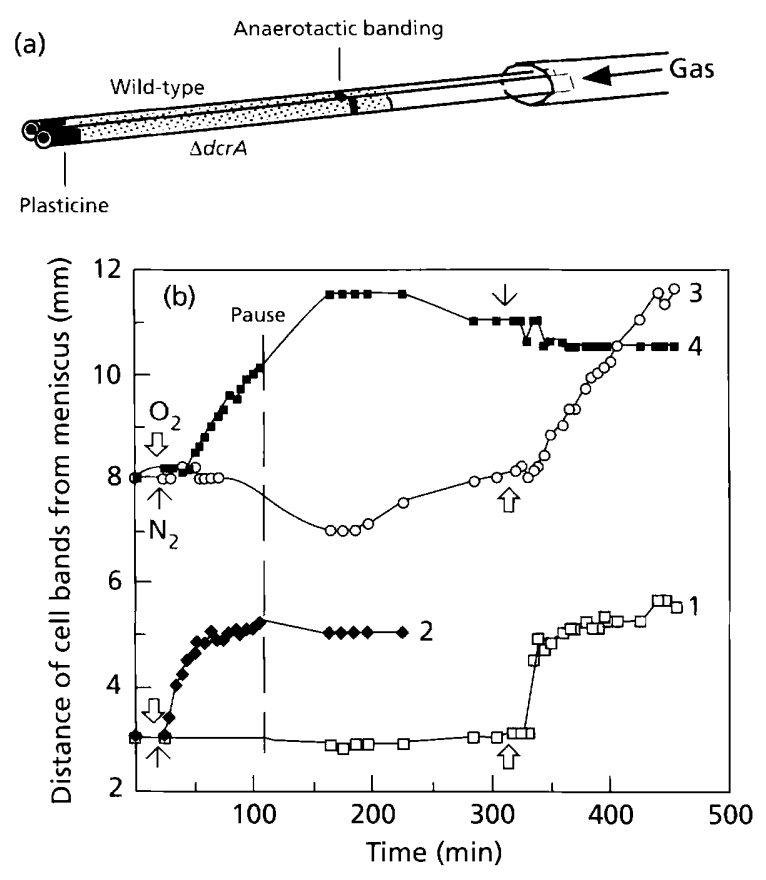

Fig. 7. Anaerotaxis assay with change of gas phase. (a) Detail of the capillary tube setup. The capillaries were filled anaerobically and sealed with Plasticine at the medium end. Following exposure to air they were loosely connected with tubing that could be perfused with either $\mathrm{O}_{2}$ or $\mathrm{N}_{2}$. (b) Effects of gas change on anaerotactic band shifting of $D$. vulgaris. TY cultures of $D$. vulgaris wild-type (capillaries 1 and 2 ) and F100 (capillaries 3 and 4) were exposed to air. After the bands were formed (at $20 \mathrm{~min}$ ) capillaries 2 and 4 were perfused with $\mathrm{O}_{2}$ (open arrow), while capillaries 1 and 3 were perfused with $\mathrm{N}_{2}$ (line arrow). Perfusions were halted at $105 \mathrm{~min}$ (dashed line), and resumed for capillaries 1,3 and 4 with a change of gas at $310 \mathrm{~min}$. The distance of the band from the meniscus is plotted against perfusion time.

assays with a gas shift the open ends of capillaries were perfused with pure nitrogen or pure oxygen (Fig. 7a). The changes in banding position from the meniscus were visually recorded with a ruler. Cell bands of both D. vulgaris wild-type and F100 strains, formed by exposure to air, shifted further away from the meniscus when oxygen was perfused into the capillaries (Fig. 7b, capillaries 2 and 4) while they remained unchanged in the nitrogen control samples (Fig. 7 b, capillaries 1 and 3 ). When oxygen was later introduced into the nitrogen control samples, the bands moved again further away from the meniscus (Fig. 7b, capillaries 1 and 3 ).

\section{Northern blot analysis}

Recent work by Pianzzola et al. (1996) has shown that the product of the rbo gene, which is present in an operon together with the gene for rubredoxin $(r u b)$ immediately downstream from $d c r A$, can complement the deleterious effects of sod deficiency in E. coli. In order to assess whether the increased oxygen resistance of D. vulgaris F100 is due to altered rbo gene expression, we compared levels of rbo-rub mRNA. The major

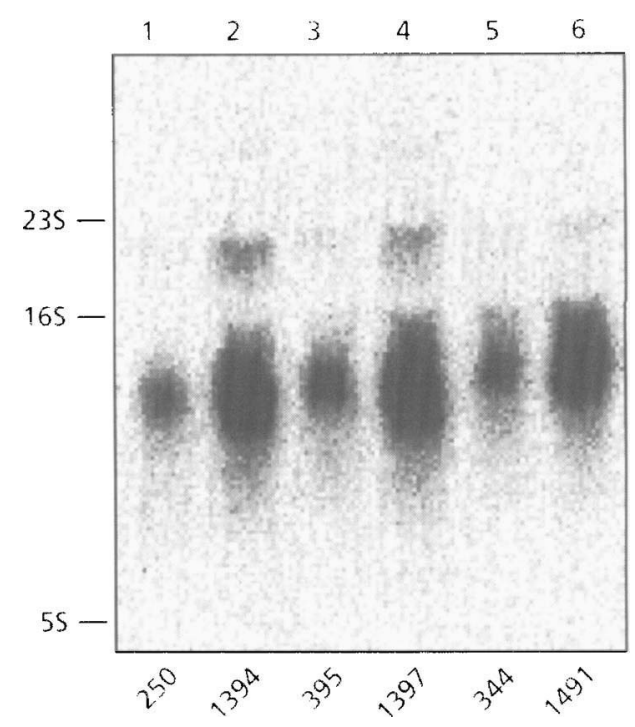

Fig. 8. Analysis of transcription of the rbo-rub operon by Northern blotting. RNA was extracted from $D$. vulgaris wildtype (lanes 1, 3 and 5) and D. vulgaris F100 (lanes 2, 4 and 6). Cells were exposed to air for 0 (lanes 1 and 2), 5 (lanes 3 and 4), or 30 (lanes 5 and 6) min prior to RNA extraction. The blot was hybridized with the ${ }^{32} \mathrm{p}$-labelled insert of plasmid pRbo1 (Brumlik \& Voordouw, 1989). The migration positions of 235 , 165 and 55 rRNA are indicated. The numbers below the lanes are the relative levels of transcript obtained by quantification with the phosphor-imaging analyser.

species of rbo-rub mRNA detected had a length of $700 \mathrm{nt}$ in both D. vulgaris wild-type and F100, in good agreement with the size reported before (Brumlik \& Voordouw, 1989). A minor species of larger size (approx. $3000 \mathrm{nt}$ ) was also present. The $700 \mathrm{nt}$ transcript was expressed at a fivefold higher level in D. vulgaris F100 compared to the wild-type under anaerobic conditions (Fig. 8, lanes 2 and 1; the same result was obtained in two experiments). Exposure to air for 5 or $30 \mathrm{~min}$ had no effect on the transcription level of the rbo-rub operon in D. vulgaris F100, while a $50 \%$ increase was recorded for the wild-type (Fig. 8, lanes 3 to 6$)$.

\section{DISCUSSION}

Prior to this work, only Rousset et al. (1991) had succeeded in using marker-exchange mutagenesis in Desulfovibrio, for construction of a [NiFe] hydrogenase gene deletion mutant of $D$. fructosovorans. These authors used electroporation to deliver the nonreplicating plasmid and penicillin enrichment for selection of the gene-replacing double recombination. The probable presence of a restriction/modification system, as documented here, prevented use of this approach for D. vulgaris Hildenborough. Attempts to electroporate plasmids into $D$. desulfuricans were also unsuccessful (Wall et al., 1993). This may also be due to a restriction problem; for example $D$. desulfuricans strain Norway harbours the restriction endonuclease DdeI (Sznyter 
et al., 1987). The conjugal transfer method with $s a c B$ counter-selection used here is less affected by host restriction (Schweizer, 1992) and does not require a specific phenotype of the target gene for selection. The physiological function of other genes from $D$. vulgaris Hildenborough which have been cloned and sequenced (Voordouw, 1995) can now, in principle, be tested with this approach.

Use of the Bacillus subtilis sacB gene as a counterselectable marker for gene-replacement mutagenesis has been successful in many other Gram-negative bacteria (Cai \& Wolk, 1990; Kamoun et al., 1992; Quandt \& Hynes, 1993; Ried \& Collmer, 1987; Schweizer, 1992; Schweizer \& Hoang, 1995). The sacB gene encodes levansucrase, which is toxic to the host in the presence of sucrose (Steinmetz et al., 1983; Gay et al., 1985). The occurrence of spontaneous sacB mutations has also been demonstrated in other systems (Cai \& Wolk, 1990; Kaniga et al., 1991) and necessitates additional screening either by monitoring the loss of an antibiotic resistance marker or, as we have done, by Southern blotting. We found a high frequency of $s a c B$ mutations $50 \%$ of all $\mathrm{Cm}^{\mathrm{R}}$ Suc $^{\mathrm{R}}$ colonies), of which $40 \%$ were due to insertional inactivation by an endogenous IS element.

The development of an efficient selection system was essential for the success of our method, because conjugal-transfer-based gene replacement requires two homologous recombination events that take place at low frequency, usually between $10^{-9}$ and $10^{-4}$ (Blomfield et al., 1991; Kaniga et al., 1991). Unfortunately, Desulfovibrio spp. have a high level of endogenous resistance to many antibiotics and many of the commonly used antibiotic resistance genes do not perform well in these bacteria (van Dongen et al., 1994). The $\mathrm{Cm}^{\mathrm{R}}$ marker is the only reliable marker found so far for selection in $D$. vulgaris Hidenborough provided that selection of plasmid integrants is done at a $\mathrm{Cm}$ concentration of $10 \mu \mathrm{g} \mathrm{ml}^{-1}$. At lower concentrations of Cm, for example $5 \mu \mathrm{g} \mathrm{m}^{-1}$ (van den Berg et al., 1989), colonies develop that lack the cat gene. Use of a recipient cell density in excess of $10^{5}$ cells $\mathrm{cm}^{-2}$ also caused wildtype cells to develop into colonies. These observations are consistent with the fact that $\mathrm{Cm}$ is only bacteriostatic and can be detoxified by cat-minus anaerobes through a ferredoxin- or NADH-dependent reduction of its aryl nitro group (Argyle et al., 1992; Staudenbauer \& Dubbert, 1993). This problem may be aggravated when $\mathrm{Km}$ selection against the $E$. coli donor cells containing the cat gene on a multicopy plasmid is inefficient.

The deletion of the $d c r A$ gene does not affect growth of D. vulgaris under anaerobic conditions (Fig. 6a, b). The earlier finding, that the degree of methyl labelling of DcrA's signal transduction domain decreased in response to oxygen (Fu et al., 1994), led to the hypothesis that DcrA allows $D$. vulgaris to recognize oxygen as a chemotactic repellent, i.e. repellents also decrease the degree of methyl labelling of MCPs in the Enterobacteriaceae (MacNab, 1987). This hypothesis would be confirmed if deletion of DcrA were to abolish the anaerotactic response (the fleeing from oxygen).
Measurement of the effect of oxygen on D. vulgaris chemotaxis is complicated by the fact that oxygen may have pleiotropic effects. Oxygen can react directly with the sulfide formed by sulfate respiration, creating novel gradients, and some sulfate-reducing bacteria, including D. vulgaris, have been reported to use oxygen as the terminal electron acceptor (Dilling \& Cypionka, 1990). With these reservations in mind, the data indicate that the $\operatorname{dcr} A$ mutant retains the anaerotactic phenotype (Fig. 7b). This observation rules out DcrA as the sole determining factor in D. vulgaris anaerotaxis. Recent work on a novel aerotaxis receptor in $E$. coli has shown that its deletion abolished aerotaxis only after a second gene was also deleted (B. L. Taylor, personal communication). Anaerotaxis of $D$. vulgaris may similarly be determined by multiple genes from the large $d c r$ gene family (Deckers \& Voordouw, 1994).

The possibility that DcrA serves as a sensor in other cellular processes should also be considered. It is of great interest in this respect that the gene for the oxygen or redox potential sensor DcrA is followed immediately by the gene for Rbo. The transcriptional start of the rbo$r u b$ operon is located only 300 bp downstream from the $3^{\prime}$ end of the $\operatorname{dcr} A$ gene and the operon is transcribed in the same direction (Brumlik \& Voordouw, 1989; Dolla et al., 1992). A role for $\mathrm{Rbo}$ in repair and/or prevention of oxidative damage can be inferred from the work of Pianzzola et al. (1996), who cloned a DNA fragment from the sulfate-reducing bacterium Desulfoarculus baarsii by functional complementation of an $E$. coli strain can only grow anaerobically due to mutations in the $\operatorname{sod} A, \operatorname{sod} B$ and $\operatorname{rec} A$ genes. The cloned fragment was found to contain the $r b o$ gene, which restored the capacity of aerobic growth. The rbo gene from $D$. vulgaris, cloned by Brumlik \& Voordouw (1989), also complemented E. coli sod deficiency (Pianzzola et al., 1996). The $r u b$ gene with which $r b o$ forms an operon in both Desulfoarculus baarsii and $D$. vulgaris is not required for the complementation in E. coli. The Northern blot data indicated that under anaerobic conditions D. vulgaris $\mathrm{F} 100$ overexpresses rbo-rub mRNA about fivefold relative to the wild-type. This could explain the increased oxygen survival of $D$. vulgaris F100. An intriguing possibility is that DcrA is involved in regulation of the expression of the $r b o-r u b$ operon through a mechanism that represses transcription under anaerobic conditions and allows increased transcription under conditions of oxidative stress. Transcription levels rise somewhat in wild-type cells upon oxygenation (Fig. 8) but do not reach the level found in D. vulgaris F100, irrespective of aeration. This may mean that the oxidative stress signal that leads to full induction of $r b o$ transcription is not mere aeration and is currently not known. Elucidation of the role and regulatory interactions of the $d c r A-r b o-r u b$ region in Desulfovibrio spp. thus requires more experimentation. The mutagenesis method described here will be a help in future work that focuses on determining the physiological role of Rbo by deletion of its gene from $D$. vulgaris. 


\section{ACKNOWLEDGEMENTS}

We thank H. P. Schweizer for providing plasmids pMOB2 and pNOT19, B. L. Taylor and coworkers for discussions on aerotaxis assays, and D. Touati for communicating her findings and for establishing that D. vulgaris rbo complements superoxide dismutase deficiency of E. coli. We thank Ms M. Jiang for technical assistance in Northern blot hybridization experiments. This work was supported by a grant from the Natural Science and Engineering Research Council of Canada (NSERC) to G.V.; R.F. was the recipient of a Full-time Postgraduate Studentship award from the Alberta Heritage Foundation for Medical Research.

\section{REFERENCES}

Argyle, J. L., Rapp-Giles, B. J. \& Wall, J. D. (1992). Plasmid transfer by conjugation in Desulfovibrio desulfuricans. FEMS Micribiol Lett 94, 255-262.

Blomfield, I. C., Vaughn, V., Rest, R. F. \& Eisenstein, B. I. (1991). Allelic exchange in Escherichia coli using the Bacillus subtilis sacB and a temperature-sensitive pSC101 replicon. Mol Microbiol 5, 1447-1457.

Brown, T. (1990). Analysis of RNA by Northern and slot blot hybridization. In Current Protocols in Molecular Biology, pp. 4.9.1-4.9.14. Edited by F. M. Ausubel and others. New York: Green Publishing Associates and Wiley Interscience.

Brumlik, M. J. \& Voordouw, G. (1989). Analysis of the transcriptional unit encoding the genes for rubredoxin $(r u b)$ and a putative rubredoxin oxidoreductase (rbo) in Desulfovibrio vulgaris Hildenborough. J Bacteriol 171, 4996-5004.

Cai, Y. \& Wolk, C. P. (1990). Use of a conditional lethal gene in Anabaena sp. strain PCC 7120 to select for double recombinants and to entrap insertion sequences. J Bacteriol 172, 3139-3145.

Deckers, H. \& Voordouw, G. (1994). Identification of a large family of genes for putative chemoreceptor proteins in an ordered library of the Desulfovibrio vulgaris Hildenborough genome. J Bacteriol 176, 351-358.

Dilling, W. \& Cypionka, H. (1990). Aerobic respiration in sulfatereducing bacteria. FEMS Microbiol Lett 71, 123-128.

Dolla, A., Fu, R., Brumlik، M. J. \& Voordouw, G. (1992). Nucleotide sequence of $\operatorname{drcA}$, a Desulfovibrio vulgaris Hildenborough chemoreceptor gene, and its expression in Escherichia coli. J Bacteriol 174, 1726-1733.

Dower, W. J., Miller, J. F. \& Ragsdale, C. W. (1988). High efficiency transformation of E. coli by high voltage electroporation. Nucleic Acids Res 16, 6127-6145.

Fu, R., Wall, J. D. \& Voordouw, G. (1994). DcrA, a $c$-type hemecontaining methyl-accepting protein from Desulfovibrio vulgaris Hildenborough senses the oxygen concentration or redox potential of the environment. J Bacteriol 176, 344-350.

Gay, P., LeCoq, D., Steinmetz, M., Berkelman, T. \& Kado, C. I. (1985). Positive selection procedure for the entrapment of insertion sequence elements in Gram-negative bacteria. $J$ Bacteriol 164, 918-921.

Johnson, M. S., Zhulin, I. B., Sarmiento, L. E. \& Taylor, B. L. (1995). Aerotaxis in the anaerobic organism Desulfovibrio vulgaris. In Proceedings of the BLAST III Meeting on Bacterial Locomotion and Signal Transduction, Austin, Texas, January 12-16, 1995, Abstract 45.

Kamoun, S., Tola, E., Kamdar, H. \& Kado, C. I. (1992). Rapid generation of directed and unmarked deletion in Xanthomonas. Mol Microbiol 6, 809-816.
Kaniga, K., Delor, I. \& Cornelis, G. R. (1991). A wide-host range suicide vector for improving reverse genetics in Gram-negative bacteria : inactivation of the blaA gene of Yersinia enterocolitica. Gene 109, 137-141.

Lillebaek, R. (1995). Application of antisera raised against sulfatereducing bacteria for indirect immunofluorescent detection of immunoreactive bacteria in sediment from the German Baltic Sea. Appl Environ Microbiol 61, 3436-3442.

Macnab, R. M. (1987). Motility and chemotaxis. In Escherichia coli and Salmonella typhimurium: Cellular and Molecular Biology, vol. 1, pp. 732-759. Edited by F. C. Neidhardt, J. L. Ingraham, K. Brooks Low, B. Magasanik, M. Schaechter \& H. E. Umbarger. Washington, DC: American Society for Microbiology.

Marmur, J. (1961). A procedure for the isolation of deoxyribonucleic acid from micro-organisms. J Mol Biol 3, 208-218.

Pianzzola, M. J., Soubes, M. \& Touati, D. (1996). Overproduction of the rbo gene product from Desulfovibrio spp. suppresses all the deleterious effects of lack of superoxide dismutase in E. coli. $J$ Bacteriol 178, 6736-6742.

Postgate, J. R. (1984). The Sulfate-Reducing Bacteria, 2 nd edn. Cambridge: Cambridge University Press.

Powell, B., Mergeay, M. \& Christofi, N. (1989). Transfer of broad host-range plasmids to sulphate-reducing bacteria. FEMS Microbiol Lett 59, 269-274.

Priefer, U. B., Simon, R. \& Puhler, A. (1985). Extension of the host range of Escherichia coli vectors by incorporation of RSF1010 replication and mobilization functions. J Bacteriol 163, 324-330.

Quandt, J. \& Hynes, M. F. (1993). Versatile suicide vectors which allow direct selection for gene replacement in gram-negative bacteria. Gene 127, 15-21.

Ramsing, N. B., Kuhl, M. \& Jorgensen, B. B. (1993). Distribution of sulfate-reducing bacteria, $\mathrm{O}_{2}$, and $\mathrm{H}_{2} \mathrm{~S}$ in photosynthetic biofilms determined by oligonucleotide probes and microelectrodes. Appl Environ Microbiol 59, 3840-3849.

Reddy, K. J. \& Gilman, M. (1990). Preparation of bacterial RNA. In Current Protocols in Molecular Biology, pp. 4.4.1-4.4.7. Edited by F. M. Ausubel and others. New York: Green Publishing Associates and Wiley Interscience.

Ried, J. L. \& Collmer, A. (1987). An nptI-sacB-sacR cartridge for constructing directed, unmarked mutations in Gram-negative bacteria by marker exchange-eviction mutagenesis. Gene 57 , 239-246.

Rousset, M., Dermoun, Z., Chippaux, M. \& Belaich, J. P. (1991). Marker exchange mutagenesis of the bydN genes in Desulfovibrio fructosovorans. Mol Microbiol 5, 1735-1740.

Sambrook, J., Fritsch, E. F. \& Maniatis, T. (1989). Molecular Cloning: a Laboratory Manual, 2nd edn. Cold Spring Harbor, NY: Cold Spring Harbor Laboratory.

Schweizer, H.P. (1992). Allelic exchange in Pseudomonas aeruginosa using novel ColE1-type vectors and a family of cassettes containing a portable ori $T$ and the counter-selectable Bacillus subtilis sacB marker. Mol Microbiol 6, 1195-1204.

Schweizer, H. P. \& Hoang, T. T. (1995). An improved system for gene replacement and $x y l E$ fusion analysis in Pseudomonas aeruginosa. Gene 158, 15-22.

Simon, R., Priefer, U. \& Pühler, A. (1983). A broad-host-range mobilization system for in vivo genetic engineering: transposon mutagenesis in gram-negative bacteria. Bio/Technology 1 , 784-791.

Staudenbauer, W. L. \& Dubbert, W. (1993). Genetics and mol- 
ecular biology of chloramphenicol acetyltransferase of Clostridium butyricum. In Genetics and Molecular Biology of Anaerobic Bacteria, pp. 174-178. Edited by M. Sebald. New York: Springer.

Steinmetz, M., Le Coq, D., Ben Djemia, H. \& Gay, P. (1983). Analyse génétique de $s a c B$, gène de structure d'une enzyme secrétée, la lévan-saccharase de Bacillus subtilis Marburg. Mol Gen Genet 191, 138-144.

Sznyter, L. A., Slatko, B., Moran, L., O'Donnell, K. H. \& Brooks, J. E. (1987). Nucleotide sequence of the $D$ deI restriction-modification system and characterization of the methylase protein. Nucleic Acids Res 20, 8249-8266.

Van den Berg, W. A. M., Stokkermans, J. P. W. G. \& van Dongen, W. M. A. M. (1989). Development of a plasmid transfer system for the anaerobic sulfate reducer, Desulfovibrio vulgaris. J Biotechnol 12, 173-184.

Van Dongen, W. M. A. M., Stokkermans, J. P. W. G. \& van den Berg, W. A. M. (1994). Genetic manipulation of Desulfovibrio. Methods Enzymol 243, 319-330.
Voordouw, G. (1995). The genus Desulfovibrio: the centennial. Appl Environ Microbiol 61, 2813-2819.

Voordouw, G., Strang, J. D. \& Wilson, F. R. (1989). Organization of the genes encoding [Fe] hydrogenase in Desulfovibrio vulgaris subsp. oxamicus Monticello. J Bacteriol 171, 3881-3889.

Wall, J. D. (1993). Genetics of the sulfate-reducing bacteria. In The Sulfate-reducing Bacteria: Contemporary Perspectives, pp. 77-87. Edited by J. M. Odom \& R. Singleton, Jr. New York: Springer.

Wall, J. D., Rapp-Giles, B. J. \& Rousset, M. (1993). Characterization of a small plasmid from Desulfovibrio desulfuricans and its use for shuttle vector construction. $J$ Bacteriol 175, 4121-4128.

Yanisch-Perron, C., Vieira, J. \& Messing, J. (1985). Improved M13 cloning vectors and host strains: nucleotide sequences of the M13mp18 and pUC19 vectors. Gene 33, 103-119.

Received 11 October 1996; revised 11 December 1996; accepted 20 December 1996. 